\title{
Gustav Mahler and Emanuel Libman: bacterial endocarditis in 1911
}

\author{
DAVID LEVY
}

The composer and conductor Gustav Mahler died in Vienna in May 1911 at the age of 51 . His terminal illness, bacterial endocarditis, was diagnosed definitively by Emanuel Libman (1872-1946) and his assistant, George Baehr (1887-1978), who at the time, together with William Osler and Thomas Horder in England, were the world's greatest authorities on endocarditis. In 1983 I initiated a search for the detailed bacteriological records known to have been kept by Dr Baehr. Dr Arnold M Weissler, of Denver, Colorado, traced them to the National Library of Medicine, Bethesda, through Dr George L Engel, nephew of Dr Libman, and Dr Manfred Waserman, formerly of the National Library of Medicine. The records, from the Mount Sinai Hospital, New York, had been deposited there after Dr Libman's death. I present them here in relation to some of the biographical and clinical details of Mahler's illness and to the state of knowledge of bacterial endocarditis in 1911, a time when many of the outstanding problems of the disease were being solved.

\section{Mahler's early medical history}

Biographies of Mahler's early life indicate that he was remarkably healthy despite his humble upbringings. ${ }^{2}$ From early adulthood he was troubled intermittently by haemorrhoids, throat infections, and various intestinal complaints, but these rarely interrupted his astonishingly rigorous schedule as an orchestral and opera conductor and composer. It is almost certain, however, that he suffered rheumatic fever as a child. There is no definite evidence for this, but several of his contemporaries, remarking on his characteristic jerky gait from his early 20 s onwards, thought that it had resulted from St Vitus' dance during childhood. This view is speculative, as is the notion that his fidgety walk was an unconscious emulation of his mother, who also died prematurely of heart disease and walked with a limp. He narrowly escaped death in Hamburg during the epidemic of cholera of 1892, which claimed Tchaikovsky's life a year later.

In 1907, when Mahler was 47, his daughter died of scarlet fever and diphtheria in terrible circumstances. From the biography of Mahler written by his wife, Alma (1879-1964), whom he married in 1902, we learn that after this tragedy Mahler was examined almost incidentally by their local general practitioner, a Dr Blumenthal. ${ }^{3}$ It was this doctor who first definitely detected the signs of compensated valvular heart disease; as far as is known, until this time Mahler had been asymptomatic. An earlier examination of his heart when he bled catastrophically from haemorrhoids in 1901 had shown it to be "solidly installed in his chest." A second opinion confirmed a valvular defect, which was reconfirmed by the eminent Viennese physician Friedrich Kovacs (1861-1931) in July 1907. Kovacs thought it serious enough to impose a regimen of severely curtailed exercise, thoroughly traditional management for the period. From Mahler's letters it seems that the diagnosis caused him both emotional and physical anguish; he was thereby prevented from taking his accustomed strenuous exercise. In a letter to Bruno Walter he wrote 4 :

My mental activity must be complemented by physical activity. The advice you pass on from doctors is of no use to me. An ordinary, moderate walk gives me such a rapid pulse and such palpitations that I never achieve the purpose of walkingto forget one's body. . . . Now imagine Beethoven having to have his legs amputated after an accident. If you know his mode of life, do you believe he could then have drafted even one movement of a quartet?

Alma suggests that his life was continually tormented by his being prevented from taking exercise, though it seems likely that he paid little more than lip service to his doctors' advice. Even recent writers have

\footnotetext{
Department of Medicine and Endocrinology, Central Middlesex Hospital, London NW10 7NS

DAVID LEVY, MA, MRCP, research registrar
}

credited him with a frail constitution, 5 and although retrospectively Alma may have placed him in an invalid role, his capacity for quite gruelling exertion remained with him until his last months. His complaints of symptoms on exertion are belied by his remarkable capacity for undertaking strenuous programmes of conducting, touring, and composing, including extensive revision of his earlier works.

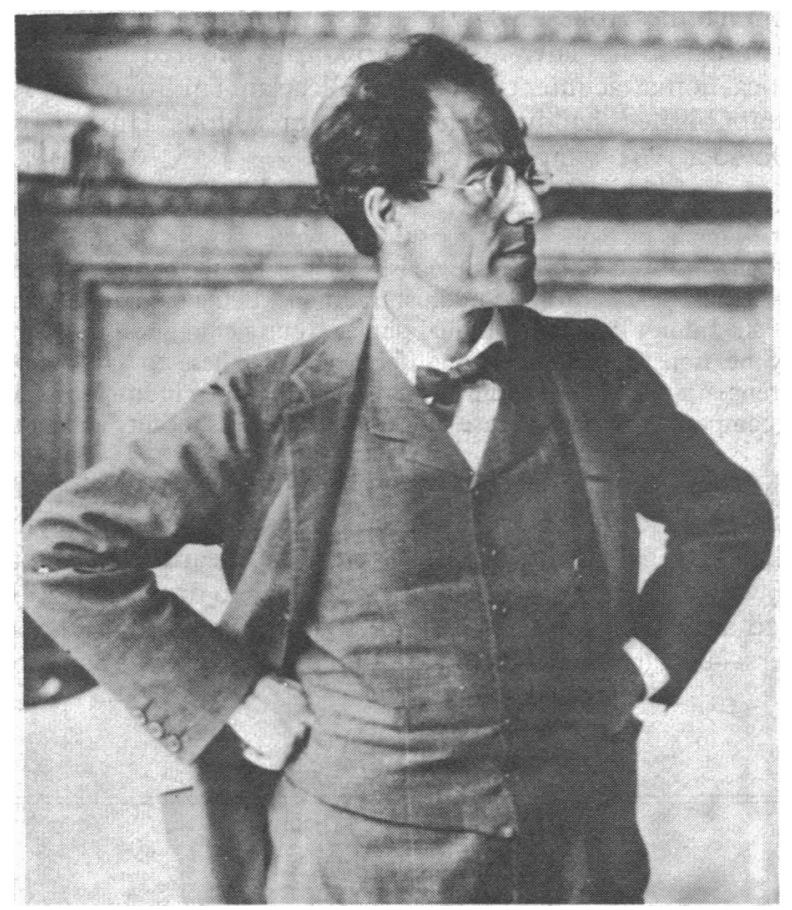

Mahler photographed in 1907. One of a series of characteristic poses, taken in the foyer of the Vienna Opera House. (By permission of the Radio Times Hulton Picture Library.)

Mahler's contract with the Vienna State Opera, which he had held since 1897, ended in 1907 as a result of a malicious antisemitic campaign, in spite of his conversion to Catholicism earlier that year. Thereafter he and his family made an annual journey to New York, where he was, first, director of the New York Metropolitan Opera and, subsequently, conductor of the New York Philharmonic Orchestra. It was widely supposed at the time that his final illness was precipitated by the strain of his American undertakings. ${ }^{6}$ This view was continued in an acrimonious debate in the Austro-German and American press after his death. ${ }^{7} \mathrm{He}$ was undoubtedly under great stress from various administrative factions, but the period was one of remarkable creativity, and his late compositions (the valedictory symphonic song cycle Das Lied von der Erde and the final two symphonies, of which No 10 was incomplete at his death) show a continuing stylistic development and a harmonic language that often approaches the atonality of Arnold Schönberg, whom he greatly admired.

Mahler was also suffering psychological trauma in his personal life. His marriage was precariously balanced. Early in 1910 he learnt accidentally that Alma was having an affair with the young architect Walter Gropius (18831969), and his mental torment is reflected in the agonised epithets scrawled in the margins of the score of the 10th Symphony. A brief psychoanalytical session with Freud in Leiden in August 1910 managed to restore mental equilibrium, which he maintained until the end of his life. This remarkable meeting was probably orchestrated by Richard Nepallek, a neurologist and 
Alma's uncle. Freud recalled the encounter much later, in 1934: he was greatly impressed by Mahler and formulated his mental state in dramatic psychoanalytical terms in a letter to Theodore Reik ${ }^{8}$ :

If I may believe reports, I achieved much with him at that time. This visit appeared necessary to him because his wife at the time rebelled against the fact that he withdrew his libido from her. In highly interesting expeditions through his life history we discovered his personal conditions for love, especially his Holy Mary complex (mother fixation). I had plenty of opportunity to admire the capability for psychological understanding of this man of genius. No light fell at the time on the symptomatic façade of his obsessional neurosis. It was as if you would dig a single shaft through a mysterious building.

\section{The final illness}

The final season in New York came to an abrupt and premature end on 21 February 1911, when after an orchestral concert Mahler was taken back to his hotel with a high fever from a further episode of tonsillitis. The frequency of similar attacks had been increasing over the previous months. His personal physician, Dr Fränkel (1867-1920), also a Viennese émigré, in whom Mahler had great faith, was in attendance. Little is known about $\mathrm{Dr}$ Fränkel's medical practice in New York (N Christy, personal communication). Alma says that he was interested in neurology, psychology, and psychiatry, but he was clearly also an astute general physician, for both George Baehr and Alma Mahler confirm that he was the first to suspect the diagnosis of bacterial endocarditis, a disease that had been widely written about only during the previous few years. In later life he became a physician at the Montefiore Hospital in New York. The Mahlers and he had become firm friends over the previous four years, and after Mahler's death he proposed marriage to Alma. She seems to have seen in him the same cold intellectual power that she had never been able to come to terms with in Mahler: "When it comes to living you're a miserable failure," she wrote to him, rejecting his advances. "At best, men like you are put between book covers, closed, pressed and devoured in unrecognisable form by future generations. But such men never live."

At first Mahler's condition seemed to improve briefly and the sore throat and fever subsided, but he soon became febrile again. Rapid fluctuations in symptoms were known to be characteristic of endocarditis. Alma reports that Fränkel suggested blood tests and that blood cultures were taken on two occasions, the first apparently by a rather incompetent surgeon from the Montefiore Hospital, who spilt at least as much blood as he collected. The result of this test is not known, and Mahler's most recent and careful biographer, Henri Louis de La Grange, suggests that Alma is mistaken in her recollection of two separate blood cultures. Baehr took his set with understandably impeccable technique. Libman's pioneering interest in blood culture had led to the collection of about 3000 sets over the previous 12 years ${ }^{10}$ and as his assistant Baehr must have had considerable opportunity to develop a painless technique. Much later, in 1970, Baehr related his experience to Dr Nicholas Christy ${ }^{11}$ :

Sometime in February 1911, Dr Emanuel Libman was called in consultation by Mahler's personal physician, Dr Fraenkel, to see the famous composer and director. Apparently Dr Fraenkel had suspected that Mahler's prolonged fever and physical debility might be due to subacute bacterial endocarditis and therefore called Libman ... in consultation. ... Libman confirmed the diagnosis clinically by finding a loud systolic-presystolic murmur over the precordium characteristic of chronic rheumatic mitral disease, a history of prolonged low grade fever, a palpable spleen, characteristic petechiae on the conjunctivae and skin and slight clubbing of the fingers. Libman telephoned me to join him at the hotel and bring the paraphernalia and culture media required for a blood culture.

From this account it is clear that Mahler's illness was already far advanced and possibly already of several months' duration. It has been suggested that if penicillin had been in use at the time Mahler might have been saved. ${ }^{12}$ This is unlikely and, of course, purely speculative.

Baehr removed $20 \mathrm{ml}$ blood, of which he used $8 \mathrm{ml}$ for subsequent culture. Alma noted, as had more eminent physicians, that venesection resulted in a temporary remission in Mahler's fever and ventured the suggestion that formal bleeding might have been beneficial.

Libman and Baehr were well aware of the hopeless outlook once the clinical impression had been confirmed bacteriologically. It is not recorded exactly what was told to Mahler at the time; Baehr and Alma Mahler, however, both write that he insisted on being told the truth and expressed a wish to die in Vienna. According to Alma, other physicians participated in weekly discussions of the case, and although no further details of these are known, there was obvious reluctance to use the new experimental treatments on such an illustrious patient ${ }^{3}$ :

Fraenkel often said that if it had not been a case of the celebrated Mahler, but just some ordinary person, lots of things might have been tried. Blood-transfusions, for example, or saline injections. "But you don't try experiments on Gustav Mahler. We must wait in the hope that nature herself will give him the strength to pull through. I could not take the responsibility."
Nevertheless, one of the experimental streptococcal vaccines (Kollargol) was tried. Horder had looked into the value of both polyvalent antistreptococcal vaccines and vaccines prepared from the specific organism isolated from blood culture and had reported on several occasions from 1908 onward that they were at best of temporary and symptomatic benefit. 31 14

After a postponement of their departure on account of Mahler's condition the family set sail for Europe early in April, Mahler now weak and debilitated. They were accompanied on the voyage by the younger composer Busoni (1866-1924), who comforted the dying man with gifts of wine and puzzles in musical counterpoint. After their arrival in Paris, where a further consultation with a European bacteriologist was thought advisable (Alma records that Metchnikov had been mentioned in New York as suitably eminent), Mahler rallied briefly, but he collapsed again after a drive in the city. They had not been able to contact the Parisian experts in advance, and because of the approaching Easter holiday they were unable to obtain the services of the eminent Widal (1862-1929). Chantemesse (1851-1919), Widal's assistant, took over the case. Mahler was transferred to a sanatorium in Neuilly, where a further blood culture was performed. Chantemesse, an experimental scientist, barely able to contain his excitement at isolating streptococci from the blood, met Alma to tell her his findings ${ }^{3}$ :

Chantemesse . . . a celebrated bacteriologist ... came to us in great delight with a microscope in his hand. I thought some miracle had happened. He placed the microscope on the table. "Now, Madame Mahler, come and look. Even Imyself-have never seen streptococci in such a marvellous state of development. Just look at these threads-it's like seaweed." He was eager to explain, to shine his light abroad. But I could not listen. Dumb with horror, I turned and left him.

As will be seen from Baehr's report, there is no reason to disbelieve this account. The blood culture yielded a heavy growth of streptococci, the like of which even Libman's experienced team had never encountered. Mahler, however, had more faith than his wife in science, and a newspaper commented that "he [Mahler] positively beamed when Chantemesse told him that he was able to confirm Fraenkel's diagnosis in every particular."15 Mahler clearly knew the outlook at this stage: in the same report it is stated that "Mahler knows of his condition. He has succeeded in getting a full picture from the doctors in America, and what he was not actually told his ready perception soon guessed."

One of Mahler's faintly ghoulish obituaries mentions that one of the serum treatments was continued "with very unsatisfactory results." As Mahler's

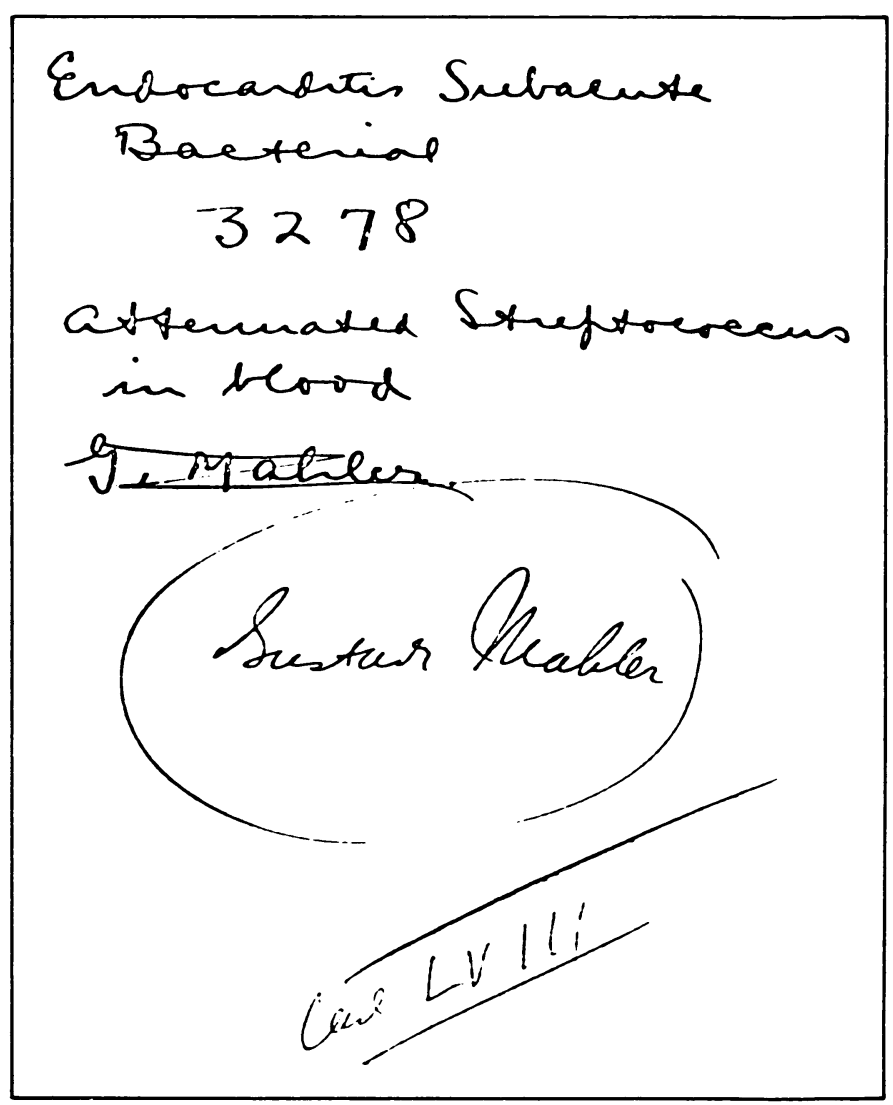

Front page of George Baehr and Emanuel Libman's bacteriological report on Mahler's blood culture. 
condition deteriorated Chvostek (1864-1944), "the most celebrated doctor in Vienna," according to Alma, was summoned to Paris around 23 April. A wise clinician, he knew how to behave with Mahler, even in the face of total helplessness, and approached the consultation with a brisk and jolly manner. Even Alma, likewise fully aware of the inevitable outcome, gained some comfort from the cheery professor, and Mahler rallied briefly once more. Again his wish was to go to Vienna, and Chvostek agreed as long as the journey was undertaken immediately. On 12 May they travelled in the Orient Express with Chvostek and Karl Moll (Alma's stepfather) in attendance.

Mahler spent his last few days at the Loewe Sanatorium, intermittently delirious. Toxic and confused, emaciated and unable to eat, he was given oxygen, caffeine, digitalis, and radium compresses for his acutely swollen joints. Despite all this attention, Alma later berated the medical profession for insensitivity during this terminal phase. She chided Chvostek for talking too loudly in the presence of the dying man, protesting that Mahler, despite his weakness, might still be able to hear. Chvostek disagreed.

Mahler died at around $11 \mathrm{pm}$ on 18 May of terminal complications of his endocarditis: pulmonary oedema, possible pneumonia, uraemia, and extreme debility. His death certificate recorded the cause of death as septic endocarditis. It also stated that a cardiac probe had been carried out post mortem. ${ }^{17}$ This was not a medical procedure. The New York Times reported that Mahler had left instructions that his heart be pierced with a needle to make sure he was really dead. ${ }^{18}$ The funeral took place at the Grinzing cemetery on 22 May, with Vienna in mass attendance. The era of the great Viennese symphonists, which had begun nearly 200 years before, was at an end-terminated perhaps some 20 years prematurely by a disease still feared and not entirely understood, which was not reliably treatable until the era of penicillin. ${ }^{19}$

\section{Libman and Baehr's report}

Baehr's bacteriological report, with, on the front page, "Endocarditis subacute bacterial 3278/attenuated streptococcus in blood/G Mahler [deleted]/Gustav Mahler [ringed]/case LVIII [both these in different hands]," was written on four pages of Mount Sinai clinical notepaper. I am grateful to Dr Arnold $M$ Weissler for providing a copy of this document. On the first page is a brief summary, written by Libman after Mahler's death:

Note, E.L.-This is a case which I saw with Dr Fraenkel. The patient had a chronic endocarditis and had been running slight temperatures for two weeks and then higher temperatures up to 104 . He was supposed to have been suffering from influenza complicating endocarditis or from rheumatic endocarditis. The blood culture was positive at once (within 16 hours). The patient died early [sic] in May.

According to Baehr's typewritten record, the cultures were set up at $630 \mathrm{pm}$ on 25 February. Four flasks and four agar plates were inoculated, using $1 \mathrm{ml}$ of blood for each. After 16 hours all four plates contained colonies, but only the fourth was subsequently kept for observation. By 48 hours 126 colonies had grown on plate 4-"pin-point in size, white in color, surrounded by a dark green zone; by transmitted light colonies are opaque, somewhat greenish in color." By 24 hours two of the flasks (A and C) contained numerous cocci; by 48 hours the remaining two flasks were heavily colonised. In flask D there was confirmation of Chantemesse's findings.

Fluid part is Burgundy in color; there is present a large amount of sedimented precipitate. Microscopically there is a large amount of precipitate present and bodies looking like mulberry bodies. In among the debris can be discerned what appears to be enormous chains of streptococci, if they are such, they are the largest we have ever encountered.

The results remained unchanged at 96 hours. In summary, wrote Baehr: The results were only of value in the glucose-serum-agar plate. The colonies were very compact, could easily be removed from the medium. There were 200 colonies to the $\mathrm{cc}$ of blood. The organism was the inulin fermenting attenuated streptococcus of sub-acute infective endocarditis. Results were positive in all flasks.

\section{Libman and endocarditis}

The bacteriology and morbid anatomy of endocarditis had been studied intensively by Libman and his colleagues in New York largely as a result of his work over the previous decade in establishing the value of blood culture in general clinical practice. As early as 1906 Libman, and Horder in England, had used blood culture to aid the diagnosis of febrile illnesses of uncertain origin, ${ }^{20}$ though it was already becoming clear during the 1880 s that endocarditis was a microbial disease. ${ }^{21}$ As a result of the new technique the detailed bacteriological findings in endocarditis were becoming clearer. Clinically, cases were being recognised with increasing frequency. The various presentations of the disease, which had caused Osler such nosological difficulty when writing his Goulstonian lectures of $1885,{ }^{22}$ were becoming more clearly delineated, and Osler and Libman were able to separate out a substantial group of subacute or chronic cases. ${ }^{2324}$ The term subacute bacterial endocarditis is Libman's own; in an article written in 1912 , by which time he had studied 89 cases, presumably including Mahler's, he disclosed that he had seen 27 cases during

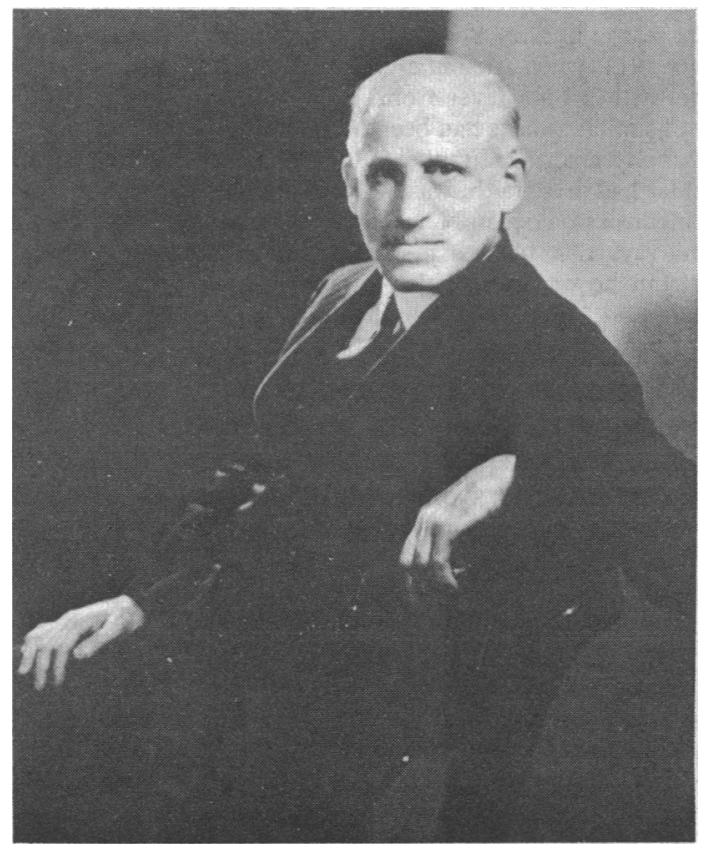

Emanuel Libman (1932). (By permission of the New York Academy of Medicine.)

the year of Mahler's death. ${ }^{24}$ Blood cultures had been taken in 75 , and 73 had yielded organisms on culture. Of these, 71 cultures grew an organism that Libman particularly associated with subacute endocarditis and had described in his paper of $1910 .^{10}$

There was considerable terminological confusion over the streptococci at the time. In Germany Schottmüller was isolating a particular streptococcus from his cases with such regularity that he regarded this organism, which he named Streptococcus mitior or $S$ viridans, as specific for subacute endocarditis, or "endocarditis lenta" as he termed the disease. ${ }^{25} \mathrm{He}$ was mistaken in this view, as both Libman and Horder had isolated influenzal organisms (Haemophilus influenzae) in a small number of cases ${ }^{26}$ and there had been reports of chronic gonococcal endocarditis on several occasions since Thayer and Blumer's first reported cases in 1896. ${ }^{27}$ Nevertheless, the attenuated streptococci of Mahler's endocarditis were entirely characteristic of the disease, and have remained so ever since. Though the origin of the microbes in the fulminating "surgical" cases of endocarditis was obvious, ${ }^{2122}$ the source of the infecting organisms in the prolonged forms of bacterial endocarditis had been the subject of much controversy, particularly in German pathological circles. Evidence was accumulating that these newly discovered non-pyogenic streptococci caused endogenous infection of valves damaged by previous rheumatic fever. It is unlikely, however appealing the idea, that Mahler's bouts of tonsillitis (presumably caused by pyogenic streptococci, as he had more than one episode of quinsy) were responsible for his infective endocarditis, though it was popularly supposed at the time of his death that his final illness dated from the death of his child in 1907, 
presumably by transmission of streptococci from her scarlet fever. It is not clear whether the elaborate procedures for applying antiseptics to the tonsils or the painful cauterisation that Alma and her daughter underwent-without anaesthetic-were arranged specifically to prevent infection passing to Gustav. The composer himself was regarded as being too sensitive to pain to undergo actual tonsillectomy, but in any case this would be unlikely to have prevented his final endocarditis.

Libman's interest in endocarditis continued, though he shared a similarly wide range of clinical and pathological interests with his older colleague in endocarditis, Osler, and treated an array of famous patients including Einstein, Sara Bernhardt, Lord Northcliffe, and Dr Chaim Weizmann. Curiously, Mahler does not figure in this list, quoted in Libman's obituary in the New York Times. ${ }^{28}$ Libman subsequently attempted to show that there may be a stage of the disease that is free of bacteria ${ }^{24}$ and provided evidence that despite the invariably fatal outcome there were cases with pathological evidence of healed lesions of previous episodes of bacterial endocarditis. He is now, of course, best known for his description with Sacks of the atypical verrucous (non-bacterial) endocarditis of lupus, in $1924 .{ }^{29}$ Baehr maintained his interest in the renal lesions of endocarditis, ${ }^{30}$ first described by Löhlein in $1910 .{ }^{31}$ Mahler's medical fate was to become a clinical and bacteriological statistic in a disease that was still baffling, and to provide a focus for some of the great physicians and medical scientists of his time in the United States and Europe. Fortunately, his musical heritage is vastly more distinguished. Both Libman and Mahler in their own disciplines represent the end of a heroic age, and it is fitting, if slightly macabre, that by a curious historical coincidence their paths should have briefly crossed.

Libman and Baehr's report was traced by Dr George L Engel of the University of Rochester Medical Center and Dr Manfred Waserman, formerly of the National Library of Medicine, Bethesda. I am grateful to the National Library of Medicine for permission to quote portions of the report and to reproduce the front page. The following also gave valuable help: $\mathrm{Dr}$ Arnold M Weissler, Denver, Colorado; Micaela Sullivan, public medical historian, American Medical Association, Chicago; Dr Nicholas Christy and Dr Saul Jarcho, New York; Nighat Ispahany, reference librarian, New York Academy of Medicine; Bridget Farrant and Sheila Cook, librarians, Avery
Jones Postgraduate Centre, Central Middlesex Hospital, London; the libraries of the British Medical Association and Mount Sinai Medical Center, New York; and Angela Edwards.

\section{References}

1 Redlich HF. Bruckner and Mahler. London: J M Dent and Sons, 1963.

2 de La Grange H-L. Mahler. Vol I. London: Gollancz, 1973.

3 Mahler A. Gustav Mahler: memories and letters. Creighton B, transl. London: John Murray, 1946.

4 Martner K. Selected letters of Gustav Mahler. London: Faber and Faber, 1979.

5 Monson K. Alma Mahler: muse to genius. London: Collins, 1984.

6 Reilly E. Guido Adler and Gustav Mahler. Records of a friendship. Cambridge: Cambridge University Press, 1982.

7 Mittag Zeitung (Berlin) 1911 May 20, quoted in New York Times 1911 May 21:part 2, p 10.

8 Kuehn JL. Encounter at Leyden: Gustav Mahler consults Sigmund Freud. Psychoanal Rev 1965-6;52:5-25.

9 Werfel AM, Ashton EB. And the bridge is love. London: Hutchinson and Co, 1959.

10 Libman E, Celler HL. The etiology of subacute infective endocarditis. Am f Med Sci 1910;140. (Reprinted Am F Med Sci 1973;266:44-52.)

11 Christy NP, Christy BM, Wood BG. Gustav Mahler and his illnesses. Trans Am Clin Climatol Assac 1970;82:200-17.

12 Kennedy M. Mahler. London: J M Dent, 1974. (Master Musicians Series.)

13 Horder TJ. Ulcerative endocarditis and its treatment by vaccine-therapy. Practitioner 1908;1: 714-22.

14 Horder TJ. Infective endocarditis; with an analysis of 150 cases and with special reference to the chronic form of the disease. $Q$ f Med 1909;1:289-323.

15 Neue Freie Presse 1911 April 22 (quoted in refs 5 and 16 ).

16 Mitchell D. Gustav Mahler: the wunderhorn years. London: Faber, 1975. (From Illustriertes Wiener Extrablatt, No 136, Friday 19 May 1911.)

17 Blaukopf K, Roman Z. Mahler—a documentary study. London: Thames and Hudson, 1976.

18 New York Times 1911 May 20:3.

19 Dormer AE. Bacterial endocarditis: survey of patients treated between 1948 and 1956. Br Med $\mathcal{J}$ 1958;i:63-9.

20 Libman E. On some experiences with blood-cultures in the study of bacterial infections. Bulletin of the Johns Hopkins Hospital 1906;17:215-28.

21 Levy DM. Centenary of William Osler's 1885 Gulstonian lectures and their place in the history of bacterial endocarditis. Journal of the Royal Society of Medicine 1985;78:1039-46.

22 Osler W. Gulstonian lectures on malignant endocarditis. Br Med f 1885;i:467-70,522-6,577-9.

23 Osler W. Chronic infectious endocarditis. Of Med 1909;1:219-30.

24 Libman E. A study of the endocardial lesions of subacute bacterial endocarditis, with particular ibman E. A study of the endocardial lesions of subacute bacterial endocarditis, with particul
reference to healing or healed lesions: with clinical notes. Am f Med Sci 1912;144:313-27.

25 Schottmüller H. Endocarditis lenta. Münchener Medizinischer Wochenschrift 1910;57:617-20.

26 Horder TJ. Bacillus influenzae as a cause of endocarditis. Transactions of the Pathological Society of London 1906;56:58-69.

27 Thayer WS, Blumer G. Ulcerative endocarditis due to the gonococcus; gonococcal septicemia. Bulletin of the Johns Hopkins Hospital 1896;7:57-63.

28 New York Times 1946 June 29:19.

29 Libman E, Sacks B. A hitherto undescribed form of valvular and mural endocarditis. Arch Interm Med 1924;33:701-37.

30 Baehr G. Glomerular lesions of subacute bacterial endocarditis. F Exp Med 1912;15:330-47.

31 Löhlein $M$. Über hämorrhagische Nierenaffectionen bei chronischer ulzeröser Endokarditis (embolische nichteiterige Herdnephritis). Medizinische Klinik 1910;6:375-9.

\section{Pie on the sly}

Dr Waguih R Guirguis (6 September, $p$ 587) describes a patient with bulimia who binged at night, apparently while sleepwalking. He postulates that a hypothalamic abnormality could account for this, although subsequent

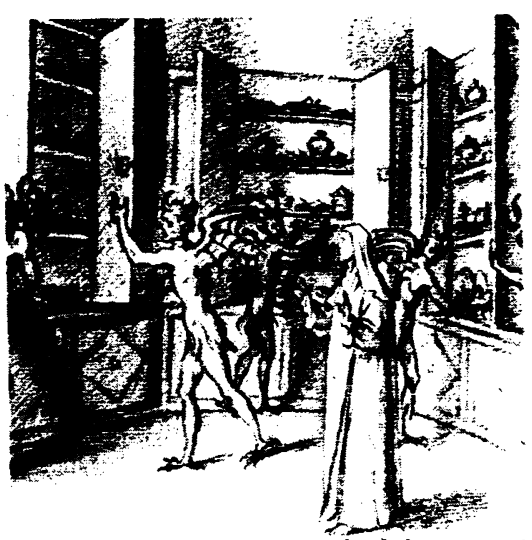
correspondence ( 8 November, $p$ 1239) cast doubt on such an interpretation. As long ago as 1669 similar behaviour was described in $\mathrm{St}$ Mary Magdalen dei Pazzi by her confessor, Virgilio Cepari.' This Carmelite mystic saint was famed for her rigorous fasting, which she underwent as an ascetic practice. When other nuns witnessed her raiding the pantry at night Fr Cepari concluded that this was not, in fact, Sister Mary Magdalen but devils who had taken on her appearance to deceive them.

We cannot help but wonder whether Dr Guirguis's credulity is due to a faith in the hypothalamus equal to that of this pious priest in his saintly colleague. In both cases, ancient and modern, less elaborate explanations, invoking social apd personal factors, seem more
sensible.-ANTHONY J PELOSI, ANTHONY S DAVID, The Maudsley Hospital, London SE5 8AZ.

1 Cepari V. Vita della serafica vergine S Maria Maddalena de' Pazzi. Bernabò: Rome, 1669.

\section{More than a skinful}

Poland and the USSR are not the only countries with major alcohol problems (11 October, p 944). Many years ago Professor Unna, the dermatologist, reported in the Zeitschrift für Haut-und Geschlechtskrankheiten a large series of alcohol related cutaneous porphyrias. In $1969 \mathrm{my}$ wife and I drove to Bucharest, and at one border town were given for breakfast a glass of about $75 \mathrm{ml}$ plum brandy, which caught fire when a match was held above it; we were told that this was the usual breakfast. Some years later I was demonstrating a patient with porphyria and was asked for an estimate of the average alcohol consumption of a male Transylvanian peasant. When I suggested about a litre of plum brandy a day I expected to be laughed to scorn, but the physician instead congratulated me on being the first Englishman who had any idea of the alcohol consumption of these people. He added, however, that he would be inclined to double my estimate-a figure which I was tempted to ridicule until I discovered that he was a graduate of a university of that region. I believe that such levels of consumption derive from isolation - in mountainous regions with low populations isolated by long narow valleys, heavy snowfall, or early nightfall. The same problem occurs in the far north of Scotland, where the "wee dram" for breakfast is a well known warning sign since it soon ceases to be wee.-GEORGE DISCOMBE, Haywards Heath, West Sussex RH16 1HH. 